\title{
Ograniczenie zużycia energii jako efekt modernizacji lokomotywy elektrycznej EU07
}

\begin{abstract}
$W$ artykule zaprezentowano wybrane aspekty modernizacji lokomotywy typu $4 E / 303 E$ serii EU07, zwiqzane z ograniczeniem zużycia energii. Lokomotywa typu 303Ea serii EU07A, powstała w wyniku modernizacji, posiada nowoczesny napęd trakcyjny z falownikami IGBT i silnikami asynchronicznymi pradu przemiennego, który umożliwia rozruch częstotliwościowy $i$ zwrot energii hamowania do trakcyjnej sieci zasilajacej (rekuperacje). Silniki napędów pomocniczych wentylatorów i sprężarek, również prądu przemiennego, sq zasilane $z$ wielowyjściowej przetwornicy statycznej z indywidualnymi rozruchami częstotliwościowymi dla każdego wyjścia. Oświetlenie zewnętrzne $i$ wewnętrzne jest wykonane w technice LED.
\end{abstract}

\section{Wstęp}

Lokomotywa EU07 powstała na bazie konstrukcji angielskiej lokomotywy EU06. Przeznaczona była do prowadzenia pociagów pasażerskich i towarowych. Produkowano ją w latach 1965 - 1974 we wrocławskim „Pafawagu” jako 4E, a następnie w latach 1983 - 1992 w Fabryce Wagonów HCP jako 303E. Łącznie powstało około 480 sztuk lokomotyw EU07. Część eksploatowanych lokomotyw była w różnym zakresie modernizowana, jednak dopiero obecna modernizacja zrealizowana wspólnie przez Instytut Pojazdów Szynowych „TABOR” w Poznaniu i ZNTK Oleśnica S.A. jest kompleksowa. W pudle pojazdu wymieniono wszystkie urządzenia i zastosowano nowoczesną aparaturę. Układy biegowe z nowymi asynchronicznymi silnikami trakcyjnymi o większej mocy przystosowano do większej prędkości $160 \mathrm{~km} / \mathrm{h}$. Lokomotywę wyposażono w mikroprocesorowy system sterowania i diagnostyki.

Widok ogólny zmodernizowanej lokomotywy przedstawiono na fot. 1 .

Podstawowe cechy lokomotywy, które uległy zmianie w wyniku modernizacji zestawiono w tabeli 1 .

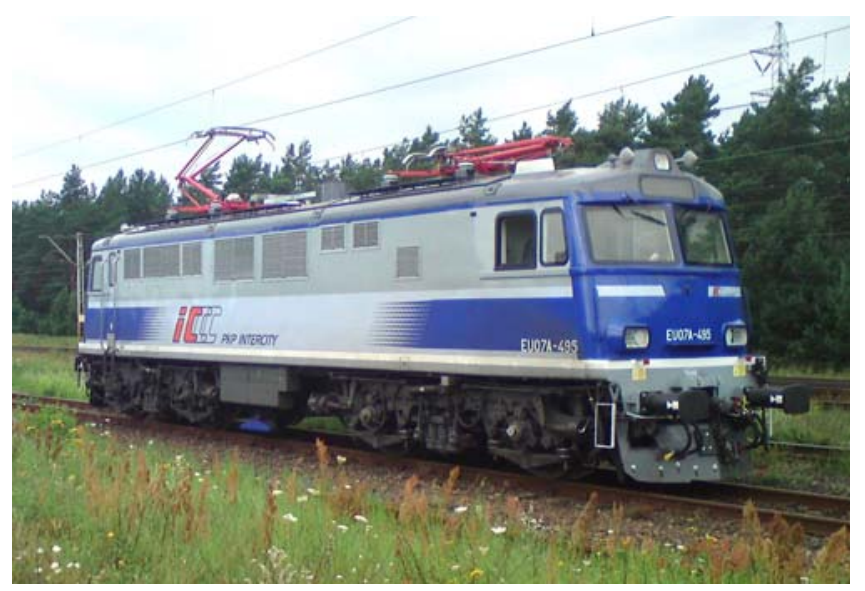

Fot. 1 Widok ogólny lokomotywy 303Ea [fot. autor]
Tabela 1. Zakres modernizacji lokomotywy EU07

\begin{tabular}{|c|c|c|c|}
\hline Lp. & Cecha & $\begin{array}{c}\text { Stan } \\
\text { przed } \\
\text { modernizacją }\end{array}$ & $\begin{array}{l}\text { Stan uzyskany } \\
\text { w wyniku } \\
\text { modernizacji }\end{array}$ \\
\hline 1. & $\begin{array}{l}\text { Moc znamiono- } \\
\text { wa lokomotywy }\end{array}$ & $2000 \mathrm{~kW}$ & $3200 \mathrm{~kW}$ \\
\hline 2 . & $\begin{array}{l}\text { Maksymalna } \\
\text { prędkość eksplo- } \\
\text { atacyjna }\end{array}$ & $125 \mathrm{~km} / \mathrm{h}$ & $160 \mathrm{~km} / \mathrm{h}$ \\
\hline 3. & Napęd trakcyjny & $\begin{array}{l}\text { silniki prądu } \\
\text { stałego }\end{array}$ & $\begin{array}{l}\text { silniki prądu } \\
\text { przemiennego } \\
\text { zasilane z falow- } \\
\text { ników IGBT }\end{array}$ \\
\hline 4. & $\begin{array}{l}\text { Układ sterowa- } \\
\text { nia }\end{array}$ & przekaźnikowy & $\begin{array}{l}\text { mikroproceso- } \\
\text { rowy }\end{array}$ \\
\hline 5. & Układ hamulca & tradycyjny & $\begin{array}{l}\text { zintegrowany, z } \\
\text { tablicą pneuma- } \\
\text { tyczną i hamul- } \\
\text { cem postojowym } \\
\text { sprężynowym, } \\
\text { współpracujący } \\
\text { hamulcem elek- } \\
\text { trodynamicznym }\end{array}$ \\
\hline 6. & $\begin{array}{l}\text { Układ przeciw- } \\
\text { poślizgowy }\end{array}$ & sygnalizacja & $\begin{array}{l}\text { automatyczny } \\
\text { dla rozruchu i } \\
\text { hamowania }\end{array}$ \\
\hline 7. & $\begin{array}{l}\text { Napędy pomoc- } \\
\text { nicze }\end{array}$ & $\begin{array}{l}\text { silniki prądu } \\
\text { stałego }\end{array}$ & $\begin{array}{l}\text { silniki prądu } \\
\text { przemiennego }\end{array}$ \\
\hline 8. & $\begin{array}{l}\text { Przeniesienie } \\
\text { napędu i zawie- } \\
\text { szenie silników } \\
\text { trakcyjnych }\end{array}$ & $\begin{array}{l}\text { wał łożysko- } \\
\text { wany ślizgo- } \\
\text { wo; } \\
\text { zawieszenie za } \\
\text { pośrednictwem } \\
\text { podkładek } \\
\text { gumowo- } \\
\text { parcianych }\end{array}$ & $\begin{array}{l}\text { wał drażony z } \\
\text { łożyskowaniem } \\
\text { tocznym; } \\
\text { zawieszenie za } \\
\text { pośrednictwem } \\
\text { elementów-ela- } \\
\text { stomero- } \\
\text { stalowych }\end{array}$ \\
\hline 9. & $\begin{array}{l}\text { Warunki pracy } \\
\text { maszynistów }\end{array}$ & $\begin{array}{l}\text { wysoki po- } \\
\text { ziom hałasu, } \\
\text { wysokie drga- } \\
\text { nia, } \\
\text { niski komfort }\end{array}$ & $\begin{array}{l}\text { zgodne z obo- } \\
\text { wiązującymi } \\
\text { normatywami }\end{array}$ \\
\hline 10. & Energochłonność & duża & optymalna \\
\hline 11. & $\begin{array}{l}\text { W skaźnik goto- } \\
\text { wości technicz- } \\
\text { nej }\end{array}$ & $\leq 0,8$ & ok. 0,95 \\
\hline
\end{tabular}



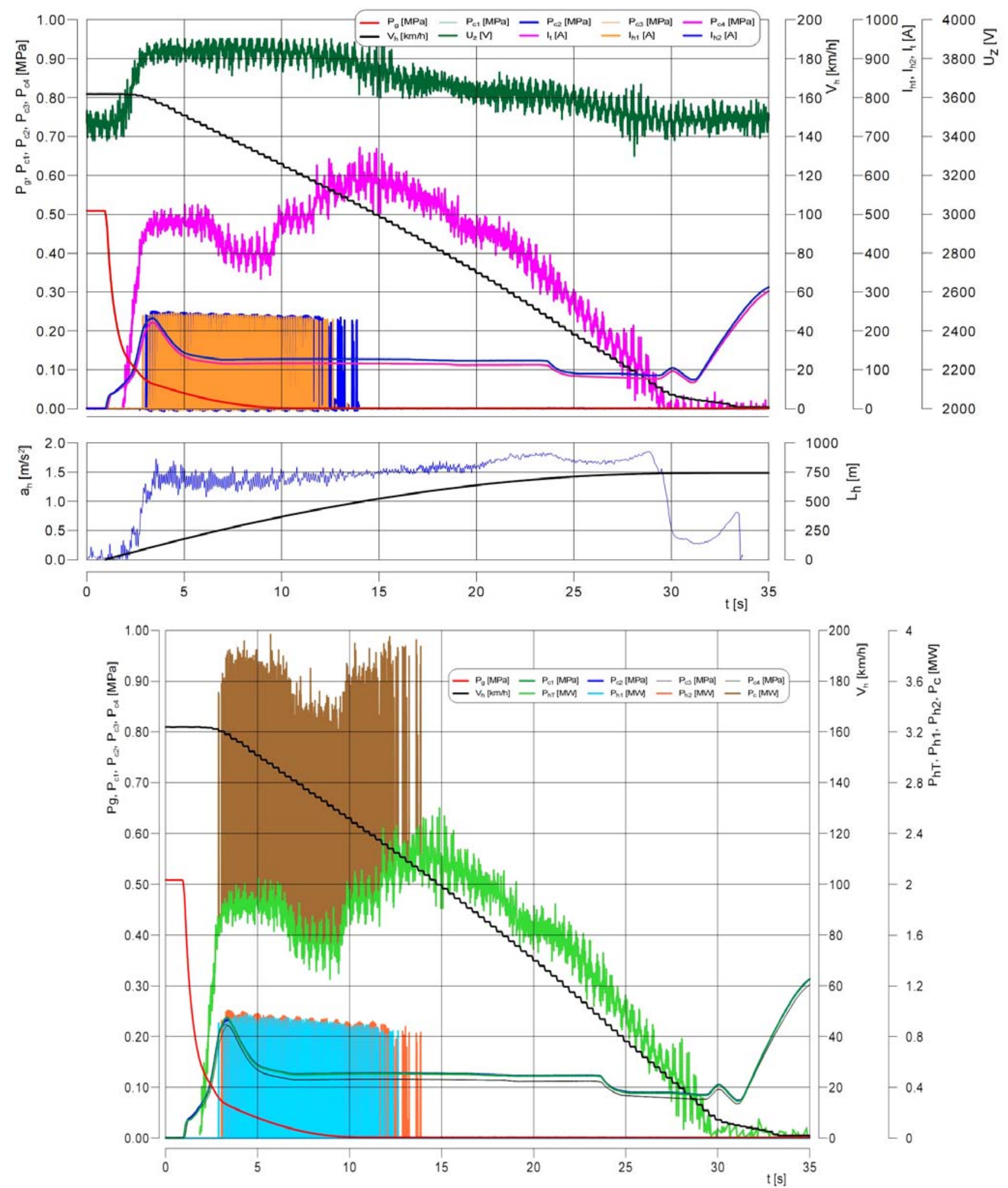

Rys. 1 Przebiegi parametrów hamowania lokomotywy 303Ea podczas hamowania elektrodynamicznego (prędkość początkowa $160 \mathrm{~km} / \mathrm{h}$, hamownie nagłe) [IPS „Tabor”]

\section{Napęd trakcyjny}

Falowniki trakcyjne FT-1600-3000 firmy MEDCOM umożliwiają rozruch, jazdę $\mathrm{z}$ zadaną siłą trakcyjna, wybieg oraz hamowanie lokomotywy. Falowniki trakcyjne zapewniają przetwarzanie napięcia wejściowego 3000 VDC na regulowane wyjściowe napięcie przemienne w zakresie od 0 do napięcia znamionowego silników trakcyjnych.

Dla osiagnięcia zwiększonej do $160 \mathrm{~km} / \mathrm{h}$ prędkości jazdy podniesiono moc silników trakcyjnych. Uzyskano to modernizując silniki EE541 (o mocy 520 $\mathrm{kW}$ ) poprzez zabudowanie $\mathrm{w}$ ich korpusach maszyn prądu przemiennego o mocy $800 \mathrm{~kW}$. Do przebudo- 
wanych przez ZNTK Oleśnica S.A. korpusów silników Zakład Maszyn Elektrycznych EMIT S.A. zamontował silniki asynchroniczne. Nowe silniki mają oznaczenie EY 541 X4.

Układ napędowy umożliwia odzysk energii hamowania, a w razie braku możliwości odbioru energii przez sieć zasilającą - hamowanie na opornik. Hamulec elektrodynamiczny współpracuje z hamulcem elektropneumatycznym. Na rys. 1 przedstawiono przebiegi zarejestrowane podczas prób homologacyjnych.

\section{Napędy pomocnicze}

Wprowadzono napędy maszyn pomocniczych z wykorzystaniem silników asynchronicznych zasilanych z wielowyjściowej przetwornicy ENI-PL3000/130/S firmy ENIKA z rozruchem częstotliwościowym. Możliwe jest sterowanie obrotami poszczególnych silników w zależności od potrzeb - np. napęd wentylatorów silników trakcyjnych uzależniony jest od temperatury ich uzwojeń (patrz tabela 2), co nie tylko daje oszczędności energii, ale również służy ograniczeniu zużycia łożysk i emisji hałasu.

Tabela 2. Regulacja obrotów wentylatorów silników trakcyjnych w lokomotywie EU07A

\begin{tabular}{|c|c|c|c|c|c|c|}
\hline $\begin{array}{c}\text { Próg } \\
\text { temperatury } \\
\text { uzwojeń silnika }\end{array}$ & ${ }^{\circ} \mathrm{C}$ & $\begin{array}{c}\leq \\
40\end{array}$ & 50 & 60 & 70 & 80 \\
\hline $\begin{array}{c}\text { Prędkość } \\
\text { względna } \\
\text { wentylatora }\end{array}$ & $\% \mathrm{n}_{\mathrm{N}}$ & 20 & 40 & 60 & 80 & 100 \\
\hline
\end{tabular}

\section{Oświetlenie zewnętrzne i wewnętrzne}

Na czołach lokomotywy zabudowano nowe projektory świateł głównych i sygnałowych firmy Pintsch Bamag (fot. 2).

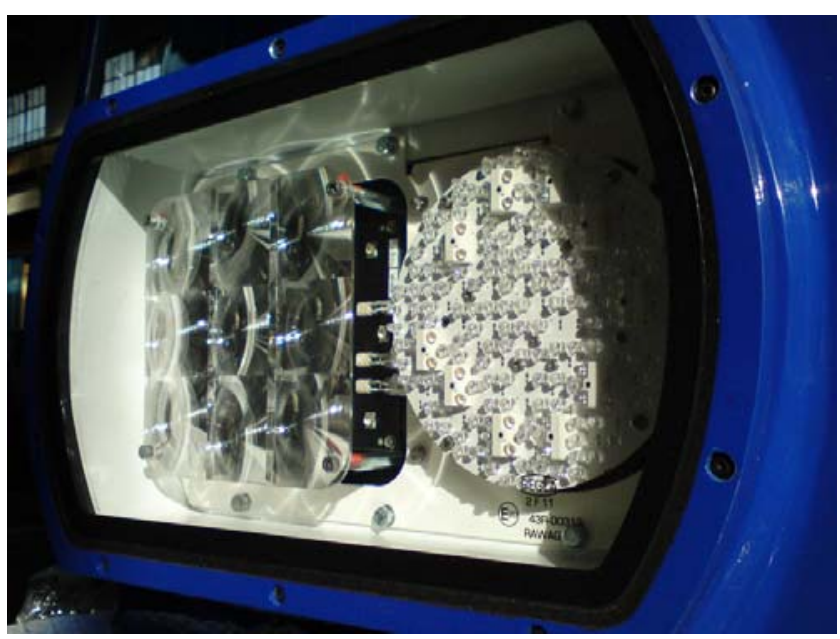

Fot. 2 Reflektor i światła sygnałowe wykonane w technice LED [fot. autor]
W kabinach maszynisty zastosowano energooszczędne oświetlenie LED $\mathrm{z}$ oprawami okragłymi firmy Teknoware z funkcją płynnego przyciemnienia oraz możliwością przełączenia na oświetlenie nocne niebieskie (fot. 3 ).

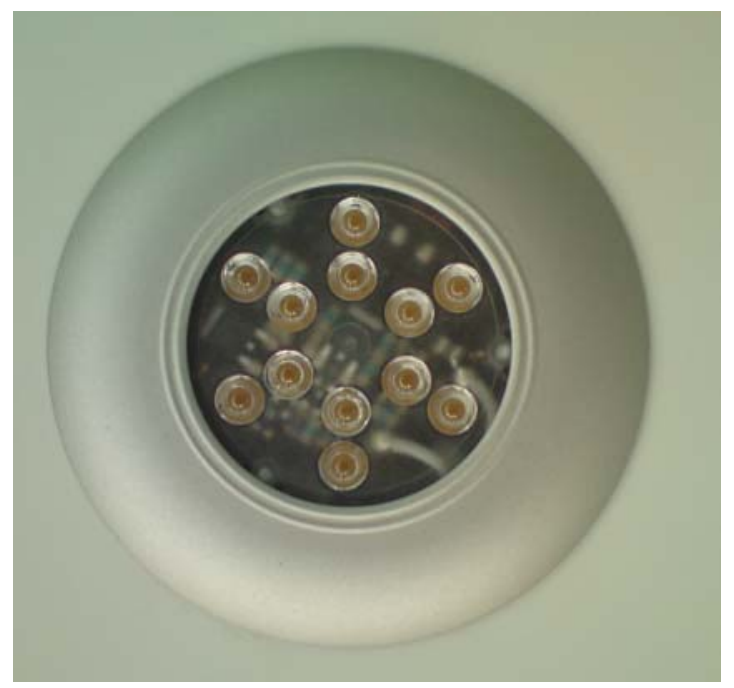

Lampa o barwie ciepłobiałej

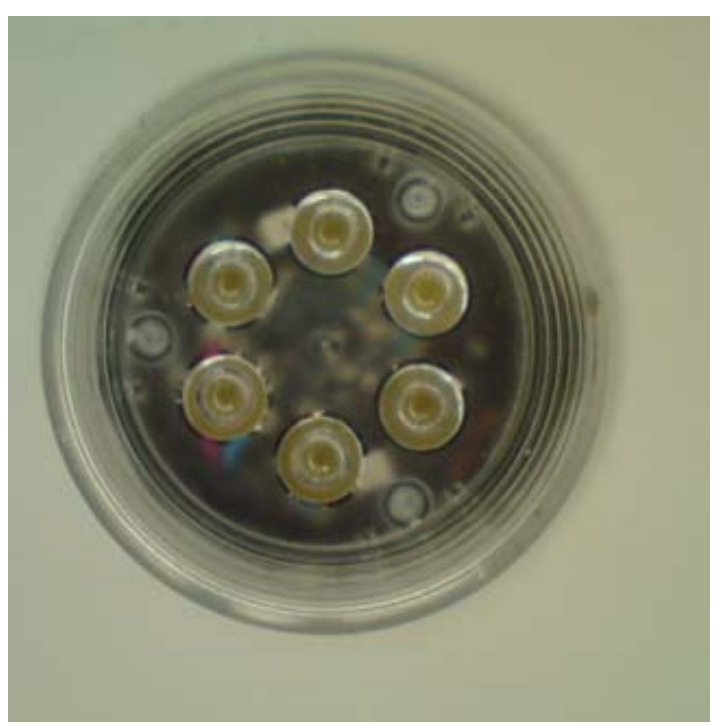

Lampa o barwie białej

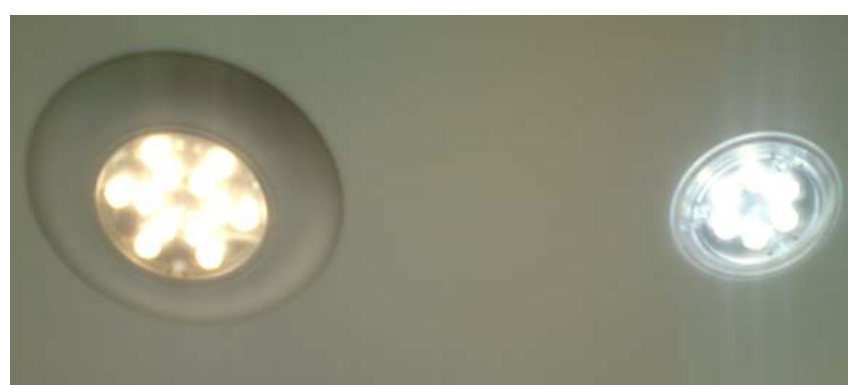

Oświetlenie pełne 


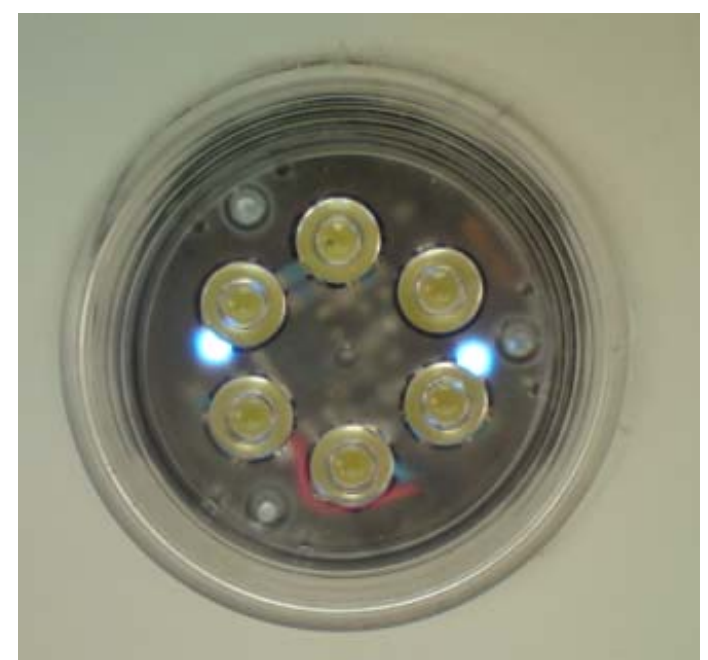

Oświetlenie nocne (niebieskie)

Fot. 3 Oprawy oświetleniowe LED zabudowane w suficie kabiny maszynisty [fot. autor]

Przedział maszyn wyposażono $\mathrm{w}$ energooszczędne oświetlenie typu LED z oprawami podłużnymi firmy Teknoware, które zapewnia odpowiednią ekspozycję poszczególnych podzespołów (fot. 4). Również tylna cześś szafy NN posiada indywidualne oświetlenie typu LED.

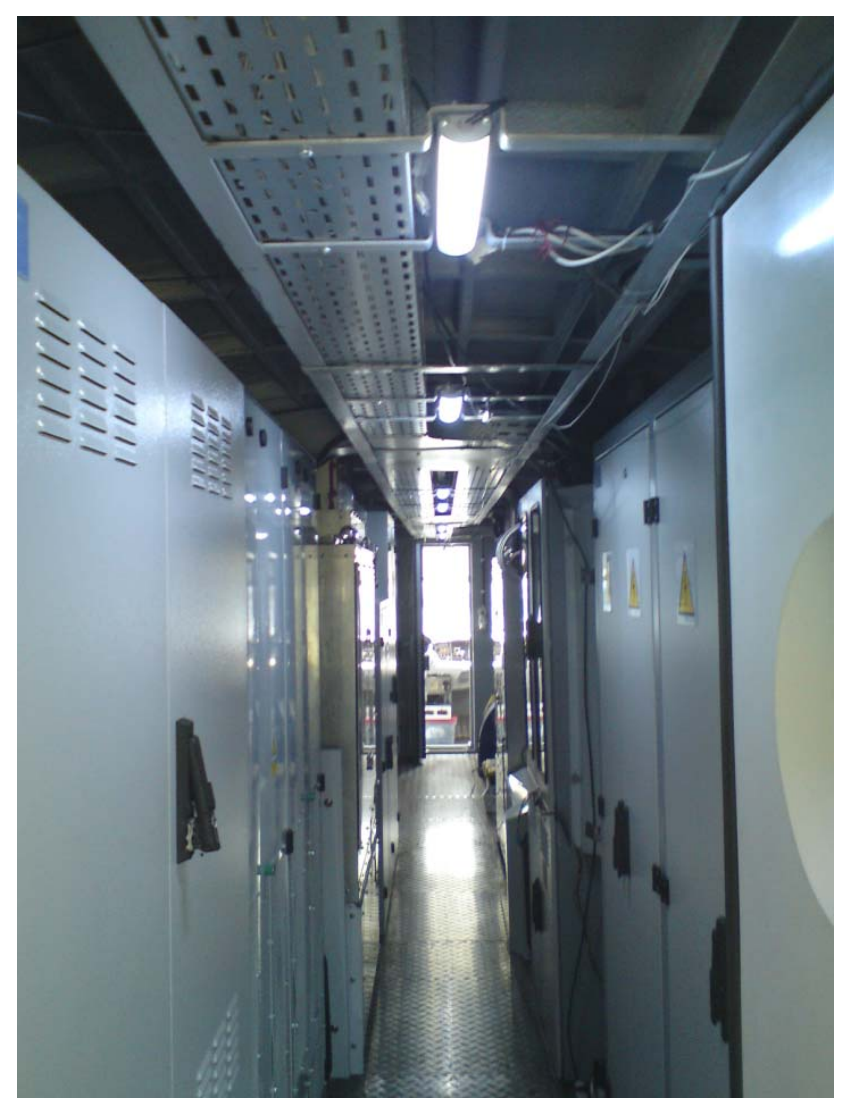

Fot. 4 Korytarz przedziału maszynowego z oprawami oświetleniowymi LED [fot. autor]
W tabeli 3 zestawiono korzyści energetyczne wynikające z zastosowania energooszczędnych źródeł światła. Dodatkową zaletą jest wielokrotnie większa żywotność lamp LED.

Tabela 3. Bilans mocy obwodów oświetlenia $24 \mathrm{~V}$ w lokomotywie EU07A

\begin{tabular}{|c|c|c|c|c|}
\hline Lp. & Rodzaj obciążenia & $\begin{array}{l}\text { Pobór } \\
\text { mocy } \\
{[\mathrm{W}]}\end{array}$ & $\begin{array}{c}\text { Pobór } \\
\text { prądu } \\
\text { [A] }\end{array}$ & $\begin{array}{c}\text { Ladunek pobrany } \\
\text { z baterii }(5 \mathrm{~h}) \\
{[\mathrm{Ah}]}\end{array}$ \\
\hline \multicolumn{5}{|c|}{ PRZED MODERNIZACJA } \\
\hline $1 \mathrm{a}$ & Reflektory halogenowe & 400 & 16,7 & 83.5 \\
\hline $2 \mathrm{a}$ & Oświetlenie wewnętrzne & 200 & 8,4 & 42 \\
\hline \multicolumn{2}{|r|}{ Razem: } & 600 & 25,1 & 125,5 \\
\hline \multicolumn{5}{|c|}{ PO MODERNIZACJI } \\
\hline $1 \mathrm{~b}$ & Reflektory LED & 100 & 4,2 & 21 \\
\hline $2 b$ & Oświetlenie wewn. LED & 75 & 3,2 & 16 \\
\hline \multicolumn{2}{|r|}{ Razem: } & 175 & 7,4 & 37 \\
\hline
\end{tabular}

\section{Podsumowanie}

Wprowadzone w wyniku modernizacji zmiany, przedstawione powyżej, podwyższają parametry techniczne lokomotywy, poprawiają warunki pracy maszynisty, obniżają koszty eksploatacji, podnoszą współczynnik gotowości technicznej lokomotywy i niwelują przepaść technologiczną między lokomotywami obecnie eksploatowanymi w Polsce a lokomotywami współcześnie produkowanymi na świecie. 